\title{
SECONDARY TARGETS? MALE WITCHES ON TRIAL
}

As the previous chapter showed, the prevailing view in witchcraft studies is that male witches were rare exceptions to the rule and are less important and interesting, as historical subjects, than female witches. There is a kind of conventional historiographical wisdom about male witches, which may be summarised as follows: male witches were a) accused in small numbers; b) accused primarily because they were related to female witches; c) accused primarily in large witch-hunts, in which panic broke down the stereotype of the female witch; d) not accused of diabolic witchcraft, especially the sexual aspects; e) accused in larger numbers in areas where witchcraft was treated primarily as heresy rather than as maleficium; $f$ ) accused of different types of witchcraft from that of female witches.

These generalisations are rarely questioned, despite the fact that they are derived, for the most part, from the early regional studies by Monter, Midelfort, and Macfarlane rather than from comparative analyses. Whereas almost everything else, it seems, about witchcraft and witch-hunting (especially anything to do with women) has been dissected under many different microscopes, these hypotheses regarding male witches, put forward in the 1970s, have been absorbed as comfortable verities and allowed to stand virtually untested.

This chapter examines cases in which men were accused of witchcraft. The examples are drawn from several different regions, in order to test conventional generalisations about male witches. Examining a few cases is not the same thing as a comprehensive comparative analysis, and 
one must be wary of merely replacing old generalisations with new ones; however, the examples discussed in this chapter indicate clearly that the conventional wisdom regarding male witches is faulty on empirical grounds and fails utterly to account for the complexity of witchcraft cases involving men.

As Robin Briggs has put it, 'Counting heads is a useful way of shaking our ready assumptions, and of bringing a degree of rigour into the discussion.' One of the most dangerous assumptions, methodologically speaking, is to impart too much significance to the often-cited fact that women comprised 75 to 80 per cent of those tried for witchcraft in early modern Europe. This figure represents an estimate that covers continental Europe, the British Isles, and the American colonies, over a period of roughly three hundred years: it masks the crucial fact that ratios of male to female witches were extremely variable. The following table illustrates this variability between regions.

Table 1 is an original synthesis of others' archival research. Similar tables can be found in many studies. Ordinarily, they are compiled in order to marshal statistical support for arguments about witch-hunting's anti-female bias. Our purpose is different, and we have designed our table accordingly. We have omitted the usual column listing the percentage of female witches, in favour of one listing the percentage of male witches. The arrangement of data is also somewhat unusual. Instead of grouping statistics by region or chronology, we have sorted them according to an ascending numerical order of the percentages of male witches. We have done this for two reasons: first, to highlight the range of percentages; second, and more importantly, to avoid, as far as possible, giving the false impression that the data sets are directly comparable. As the second column shows, the chronological periods covered are too variable to allow a meaningful comparison of statistical data; in addition, the regions represented in this sample are very different, ranging from a city (Venice) to entire countries. Our sample is by no means intended to be exhaustive; therefore, we have not included totals. The 
Table 1 Witchcraft prosecutions by sex ${ }^{2}$

\begin{tabular}{llrrr}
\hline Place & Dates & Female & Male & \% Male \\
\hline Bishopric of Basel & $1571-1670$ & 181 & 9 & 5 \\
Hungary & $1520-1777$ & 1,482 & 160 & 10 \\
Essex Co., England & $1560-1602$ & 158 & 24 & 13 \\
SW Germany (executions) & pre-1627 & 580 & 88 & 13 \\
New England & $1620-1725$ & 89 & 14 & 14 \\
Scotland & $1560-1709$ & 2,208 & 413 & 16 \\
Norway & $1551-1760$ & $c .690$ & $c .173$ & 20 \\
SW Germany (executions) & post-1627 & 470 & 150 & 24 \\
Venice & $1550-1650$ & 714 & 224 & 24 \\
S. Sweden & $1635-1754$ & 77 & 25 & 25 \\
Fribourg & $1607-1683$ & 103 & 59 & 36 \\
Zeeland & $1450-1729$ & 19 & 11 & 37 \\
Pays de Vaud & $1539-1670$ & 62 & 45 & 42 \\
Finland & $1520-1699$ & 325 & 316 & 49 \\
Burgundy & $1580-1642$ & 76 & 83 & 52 \\
Estonia & $1520-1729$ & 77 & 116 & 60 \\
Normandy & $1564-1660$ & 103 & 278 & 73 \\
Iceland & $1625-1685$ & 10 & 110 & 92 \\
\hline
\end{tabular}

figures include men and women who were accused, indicted or tried for witchcraft.

Although it is difficult to draw certain kinds of specific conclusions from the comparison of such diverse data sets, several features stand out. First, for a phenomenon described by one historian as the exemplification of 'men's inhumanity to women', there is a suspiciously large number of cases against men: 2, 298 in this sample. ${ }^{3}$ Second, as mentioned above, the proportion of male to female witches could be extremely varied. The statistical range from 5 per cent male witches in the Bishopric of Basel to 92 per cent in Iceland, with other regions 'filling in' the gap between those two figures, makes the value of general estimates seem highly dubious. Finally, there were regions of Europe where 
men actually comprised the majority of those accused of witchcraft: Burgundy, Estonia, Normandy and Iceland.

Perhaps we could discount Iceland and Estonia as peripheral to European culture and therefore not representative of the whole; but what about Burgundy and Normandy? In any case, it is clear that any attempt to establish representativeness would be problematic. Is the Bishopric of Basel really more representative of gendered patterns of witch-hunting than Iceland, because it tried so many more women than men? Or is Norway truly representative, on the basis of its 'perfect' number of male witches?

G.R. Quaife exemplifies scholars' difficulty in coming to grips with the fact of male witches. In his discussion of the gender bias of witch hunts, Quaife explains male witches away as the political opponents of prosecutors; as cunningmen; or as relatives of female suspects. He actually suggests that in the case of New England, the male witches who were related to a female witch 'should be discounted' in an assessment of gender bias because they were merely 'secondary targets as husbands or associates of a female witch'. Discounting these men, he argues, raises the proportion of women in the New England trials to almost 90 per cent, which, he says, corresponds neatly with the proportion in England. Quaife extrapolates from this result that 'the gender bias against women may be greater in other jurisdictions than the raw figures indicate'. ${ }^{4}$

In his attempt to 'improve' the proportions of accused women, Quaife fails to consider that a statistical criterion ought to be applied to an entire set of data, not to a pre-selected group only. If, as he suggests, 'secondary' targets of witchcraft accusations ought to be discounted, then the total number of witches must drop sharply. It was unusual for more than a small number of individuals to be accused as primary targets; the ordinary pattern for witch-hunts, including the New England trials, was for primary targets to accuse directly or implicate indirectly several secondary targets, including both male and female relatives and associates. Discounting all secondary targets would alter the statistical picture significantly. Quaife, however, avoids this result by constructing 
a double standard, which presupposes, by implication, that early modern Europeans did not 'mean it' when they accused men of being witches but were serious when they accused women. That Quaife is able to suggest this without providing any qualitative evidence of early modern beliefs about male witches indicates the power of statistical figures within witchcraft historiography. ${ }^{5}$

The point here is not to deny that, generally speaking, more women than men were accused of witchcraft. This is a central, indisputable feature of early modern witch-hunting that cannot be ignored. Nevertheless, it is a feature that is far from uniform, and that lack of uniformity must be taken into account in analyses of gender and witchcraft in early modern Europe. The 'big picture' was not monochromatic, even on the often-polarised field of gender; it needs to be shaded in, nuanced, to reflect its polychromatic character. One means of accomplishing this goal is to make the men accused of witchcraft visible through specific case studies.

\section{John Samond, Essex}

Our first case study comes from the county of Essex in England. The Calendar of Assize Records contains the well-known Essex indictments, records which Alan Macfarlane plumbed for his path-breaking 1970 study Witchcraft in Tudor and Stuart England. Macfarlane noted that Essex witches were usually women, and found that of the twentythree men accused, 'eleven were either married to an accused witch or appeared in a joint indictment with a woman. ${ }^{6}$ This fact has been reiterated by several authors in order to make the male witches 'invisible', as we argued in our first chapter. Marianne Hester, for instance, barely mentions male witches in her revisionist analysis of the Essex trials, except to remark that '[i]n England more than 90 percent of those formally accused of witchcraft were women, and the few men who were also formally accused tended to be married to an accused witch or to appear jointly with a woman'.7 Joseph Klaits also refers to the Essex 
data, using them to support his assertion that 'many of the accused men were implicated solely due to their connection with female suspects.'

These statements, including Macfarlane's, assume that the women involved in the eleven cases were accused first and were the cause of the accusations against the men. This is problematic because the indictments, which provide the bulk of the evidence for any interpretations of witchcraft in Essex, contain little in the way of detailed information about individual cases. In some instances, it is possible to work out who was most likely to have been accused first. For example, in August 1579 Richard Presmary and his wife Joan were indicted and convicted at the Chelmsford Assizes on the charge of murder by witchcraft. Joan Presmary had been indicted for witchcraft in the previous year, at the Brentwood Assizes of July 1578.9 Richard Presmary had no prior indictments. It seems reasonable that in this case Joan Presmary may have been accused first, because she would have had a reputation as a witch. This tells us nothing about why Richard Presmary would have been accused this time, but it does appear to support the suggestion that men were secondary suspects.

On the other hand, in many cases there is no way of knowing, from the indictments, who was accused first. William and Margery Skelton, a couple from Little Wakering, were indicted and convicted on multiple counts of murder by witchcraft at the Chelmsford Assizes of March 1573. Neither one appears to have had previous indictments. This case is especially interesting because the four murders are divided up evenly between the couple: William bewitched one girl, Margery bewitched another, and the couple committed the remaining murders together. There is nothing in the indictment record to indicate which of the Skeltons first fell under suspicion, or who was the 'lead' witch. ${ }^{10}$ Similarly, Richard Dune and Agnes Dunne were indicted for witchcraft together in July 1589; since neither had ever been indicted previously, there is no way of knowing which one of them was the primary suspect. ${ }^{11}$

It may very well have been that in all of these cases it was the woman who first 'attracted' the charge of witchcraft, and that the men were 
suspected merely because of their association with them. The case of John Samond, however, suggests that it was equally possible for men to be suspected independently; furthermore, this case suggests that women may at times have been the secondary suspects.

John Samond, also known as Smythe, Smith, or Salmon, first appears in the Essex indictment records in July 1560, three years before the Witchcraft Statute of 1563 was passed. ${ }^{12}$ On this occasion, he was charged with having bewitched with fatal consequences John Graunte and Bridget Pecocke, who died on 28 May 1560 and 29 August 1560 respectively. He was acquitted the following year, at the Chelmsford Assizes of March 1561. ${ }^{13}$ Samond reappears several times in the Essex Assize records, usually on a charge of witchcraft, until his final indictment in 1587 , at which point he was found guilty and sentenced to be hanged. ${ }^{14}$

Samond is an important figure because his frequent appearances in the indictment records allow us to compare his charges with those of the women indicted at the same assizes. His indictments demonstrate that, contrary to some of the generalisations described at the beginning of this chapter, men could be accused of witchcraft independently of their female relatives and were not always accused of practising magic that was different from that of women. Indeed, the striking thing about John Samond, besides his frequent appearances before the assizes, is that there is no clear distinction between him and the female witches indicted in Essex.

In 1560, at the time of his first indictment, Samond was a beerbrewer with a reputation. The indictment states that

John Samond of Danbury..., beer-brewer, otherwise called John Smythe, is a common enchanter and witch as well of men as beasts ... not having God before his eyes, but being moved and seduced by the instigation of the Devil, by the devilish arts of enchantment and witchcraft, on 28 May, 1 Eliz. and diverse days and places as well before as afterwards, at Danbury aforesaid, of his malice aforethought, a certain John (sic) Graunte and Brigit Pecocke did 
bewitch and enchant, by reason of which the said Brigit ... until 29 August next following did languish, on which day the said Brigit ... died. And the said Antony Grant ... from the 28 May in the year above said until the 28 May next following did languish, on which day the said Antony ... died. ${ }^{15}$

There is no explanation of why or how he bewitched his victims, but this is normal for indictments, which are very terse documents. What is interesting here is the identification of Samond as a "common enchanter and witch'. ${ }^{16}$ The language used to describe him is the same as that used to describe a woman, Margery Stanton, at the 1579 Chelmsford Lent sessions. In Latin, the indictment against Samond reads: 'Johanes Samond ... communis incantator ac fascinator tam hominum quam animalium'. ${ }^{17}$ The indictment against Stanton is virtually identical: 'Margeria Stanton ... existens communis incantatrix et fascinatrix tam hominum quam bestiarum et aliarum rerum'. ${ }^{18}$ The two witches are differentiated only by the use of appropriate masculine and feminine endings for the words 'incantator/ incantatrix' and 'fascinator/fascinatrix'. If English people believed that there was an essential distinction between male and female witches (as witches), this is not reflected in their legal language. 19

Samond's next appearance at the assizes, in March 1570, was on a charge of grand larceny. He was accused of stealing sheep from two other men, found guilty, but allowed benefit of clergy. ${ }^{20}$ At the same assizes, two women, both from the village of Little Baddow, were indicted for murder by witchcraft; one was found guilty, the other acquitted. ${ }^{21}$

In August 1572, John Samond was indicted again for witchcraft. This time, he is listed as a yeoman and beer-brewer, and his wife Joan is indicted with him. This case is important for what it suggests - or, more precisely, for what it does not suggest - regarding the relationship between male witches and their wives.

We have seen that modern scholars tend to assume a causal relationship in which the man is accused because of his association with a 
female witch. Although there is not enough information given in the indictments to say with any certainty what the background to this case was, it seems unlikely that suspicion of Joan Samond would have led to suspicion against her husband, instead of the other way around. John Samond had a reputation for witchcraft that had landed him in court before, whereas this was his wife's first indictment. Furthermore, the charges themselves suggest that suspicion may have fallen on John first. The first charge against John Samond is for bewitching to death two cows belonging to William Treasure. This is the most recent of the three bewitchings listed in the indictment and, significantly, Treasure had given evidence against Samond in the 1570 sheep-stealing case. Treasure may have suspected an act of revenge and accused John Samond; the other charges against John and his wife (maiming one man and laming another) may have been brought forward subsequently. 22

Two other witchcraft cases at this session show that the type of charges against John Samond were not gender-specific. Agnes Francys was found guilty of bewitching a horse and three people, and Agnes Steademan was found guilty of bewitching a woman and four cows so that they became 'violently ill'. ${ }^{23}$ In 1587, Samond was indicted for murdering a woman by witchcraft. Three women, indicted at the same assizes, were charged with killing livestock and a person by witchcraft. ${ }^{24}$ There is nothing in these indictments to suggest that there was a divide between men's and women's witchcraft.

The main difference between Samond and the women accused of witchcraft at the same assizes is that the women (except for his own wife) were generally found guilty, while he was acquitted. It is tempting to conclude that Samond was acquitted because he was a man; however, it is important to remember that conviction rates for witchcraft in England were relatively low for both women and men. On the Home Circuit, fewer than half of the witchcraft indictments resulted in convictions, and only 22 per cent of those indicted were executed. ${ }^{25}$ In English witchcraft trials, a guilty verdict was by no means a foregone conclusion, and there are many cases in the Essex records of women going free. 
In any case, Samond's luck ran out later in 1587, at an assize session that demonstrates how difficult it is to draw solid conclusions about the role of gender in witchcraft prosecutions. Samond was indicted at the Chelmsford Assizes in July, on the charges of bewitching Henry Hove 'so that he languished until 5 Apr. and then died' and of killing a cow by witchcraft. Samond was tried before a grand jury, found guilty, and sentenced to be hanged. At the same session, two women were also indicted for witchcraft: they were acquitted. ${ }^{26}$

Despite Samond's many indictments, we do not know very much about him. There is simply not enough information in the indictments to enable us to say with any certainty why he was finally convicted in 1587. If all of the accused witches at that assize session had been convicted, we could surmise that they faced a 'hanging' jury that simply found everyone guilty; but the acquittal of the two women prevents us from reaching that conclusion. Perhaps, after twenty-seven years, Samond had exhausted the court's and community's patience. We cannot know, and in that sense John Samond does not help us establish explanatory models; but then, that is why he is so valuable. Samond is almost as much of a nuisance to modern scholars looking for patterns as he was to his community of Danbury. He muddles the patterns, and in doing so forces us to re-examine our assumptions about both male and female witches.

\section{Chonrad Stoeckhlin, Oberstdorf}

From 1587 to 1592, a wave of witch trials rolled across the prince-bishopric of Augsburg. In one district, Oberdorf, the trials claimed sixtyeight lives: 'the single largest persecution to be found anywhere between the Danube River and the Alps.'27 This wave began in the judicial district of Rettenberg in 1586, when Chonrad Stoeckhlin, a herdsman in the alpine village of Oberstdorf, accused Anna Enzensbergerin of being a witch. Stoeckhlin's accusation initiated a series of trials that resulted in the executions of approximately twenty-five people, including Stoeckhlin himself. Although both men and women were accused 
during the course of the trials, all of those executed in the district of Rettenberg, except for Stoeckhlin, were women. ${ }^{28}$

This case appears, on the surface, to reflect a simple anti-female dynamic. Several women were burned at the stake on the word of a man, and those men who were also accused managed to escape the fire. Wolfgang Behringer, whose microhistory of Chonrad Stoeckhlin provides the basis for this discussion, suggests, plausibly, that the court accepted accusations against women more readily than accusations against men, and that men were more likely to flee when they were accused. ${ }^{29}$ The fact that one man was executed may not seem significant when viewed against the number of women who died.

The case of Chonrad Stoeckhlin is significant, however, precisely because the trials at Rettenberg were so biased against women. In a context that appears almost uniformly misogynist, Stoeckhlin, like John Samond, confuses the pattern and forces us to ask more questions about the relationship of gender to witch trials and contemporary knowledge about witches. Also like Samond, Stoeckhlin fails on several counts to fit the model of the male witch constructed by modern scholars. He was accused independently of a close female relative (there was a connection with a female relative, but not in a way which conforms to the model: see note 43); he was accused at the very beginning of a witch panic, not in its later stages; and he was accused of the most stereotypical elements of witchcraft: the pact with the Devil, night flight to the Sabbath, and sexual intercourse with the Devil.

How did Stoeckhlin become a witch? His complex path to the stake has been reconstructed by Wolfgang Behringer from the court records of his trial. Born in 1549, Chonrad Stoeckhlin was the horse wrangler of Oberstdorf, a position of responsibility and considerable status. According to Behringer, 'The post of horse wrangler was the most eminent in the hierarchy of herdsmen, well above the more numerous herdsmen for oxen, cows, goats, sheep, and geese.... [H] orses were regarded as prestige animals, whose care demanded the greatest attention and the highest qualifications.' Stoeckhlin was married, and he and his wife had 
seven children, of whom only two survived infancy. He inherited his position as horse wrangler when his father went blind in 1567. His mother died in 1571, a year of famine. Stoeckhlin and his family were not wealthy, but they seem to have been comfortable: they had a house and were able to keep a cow in the wintertime. ${ }^{30}$

In February 1578, Stoeckhlin and his friend Jacob Walch, an oxherd, spent an evening drinking wine and talking about death and the afterlife. They made a pact with each other that "whichever of the two should die first should come to the other one ... and [should] show him what it is like in that world.' Eight days later, Walch died suddenly. After another eight days, while Stoeckhlin was out in the woods, Walch's spirit appeared to him and told him to repent his sins. ${ }^{31}$ Stoeckhlin and his family took this instruction seriously, and after a year of penance Stoeckhlin was rewarded by a visit from what would turn out to be his personal angel. This angel, which Stoeckhlin described to his interrogators as 'a person dressed in white with a red cross on his (or her) forehead', transported him to 'a strange and distant place' where he witnessed 'pain and joy'. The angel became Stoeckhlin's 'soul-guide'; it appeared several times a year to take him on soul-journeys as part of a group Stoeckhlin called the phantoms of the night (die Nachtschar). ${ }^{32}$

In addition to his responsibilities as a herdsman, Stoeckhlin was a healer. ${ }^{33}$ It was not unusual for herdsmen to function as healers of both animals and humans: 'Herdsmen served ... a veterinarians; like blacksmiths, midwives, and executioners, their help was much in demand for human sicknesses too', including illnesses caused by magic. ${ }^{34}$ Stoeckhlin's contact with the supernatural realm of the Nachtschar increased his perceived powers and led his fellow villagers to connect his healing abilities to special powers of identifying those who had caused magical illnesses. He became a witch-finder: he named the witches responsible for injuries and sicknesses, and knew how to force them, ritually, to undo their evil magic. ${ }^{35}$

In the spring of 1586, someone in Oberstdorf consulted Stoeckhlin about a string of injuries. The horse wrangler determined that a 
sixty-year-old woman, Anna Enzensbergerin, was the culprit, and urged her to reverse her spell. Instead of doing so, however, Enzensbergerin fled the village for a time. When she returned, the authorities of Oberstdorf arrested her on 'the bare testimony' of Stoeckhlin, who had learned she was a witch from the leader of the night phantoms. This accusation would prove to be Stoeckhlin's undoing. The district authorities sent an inquiry regarding the case to the Dillingen Ruling Council. The Council ruled that Enzensbergerin should be held in custody, Chonrad Stoeckhlin should be questioned, and an executioner should be found "who would know "how to torture these kinds of people"'. Around 27 July, Stoeckhlin was arrested and taken to Fluhenstein Castle, near Sonthofen. His first hearing took place on 29 July, when he was questioned by the district judge, district governor, and county clerk. ${ }^{36}$

Why arrest Stoeckhlin, a respectable and respected member of the community, whose powers were for healing, not harming, people? Stoeckhlin was not, by our standards, and certainly not by his own, a witch; however, the officials of the bishopric of Augsburg seem to have found it all too easy to suspect him of being one. They knew that he had accused Enzensbergerin, and they knew about his nocturnal flights. At the first hearing, they questioned Stoeckhlin about his journeys. He explained that there were three kinds of journey: that of the Nachtschar; the 'righteous journey' in which 'the dead are led to their places'; and the witches' flight. Stoeckhlin said that he never flew with the witches and knew nothing about their flight, but his story meshed too well with his learned interrogators' knowledge of witches to allay their suspicions. Aerial flight, at night, with a group of mysterious men and women, led by an 'angel' ... as far as the authorities were concerned, what Stoeckhlin described to them was the witches' flight to the Sabbath, led by Stoeckhlin's 'sex-devil'. ${ }^{37}$ Their image of Stoeckhlin was not improved when Anna Enzensbergerin and Barbara Luzin, his deceased mother's stepsister, not only confessed to being witches but also claimed that they had learned all they knew from Stoeckhlin's mother, Ursula Schedlerin. Ironically, Stoeckhlin had accused both women himself. 38 
On the basis of Stoeckhlin's initial hearing and the confessions of Enzensbergerin and Luzin, the district officials compiled a lengthy questionnaire of 146 items. The questions reveal the primary elements of their belief that Stoeckhlin was a witch: no one could recognise witches unless he already belonged to their society; the Nachtschar were really witches flying to the Sabbath; Stoeckhlin's angel was a black sex-devil; Stoeckhlin's mother was a witch; and several of Stoeckhlin's children had died early, possibly sacrificed to the Devil or used to make witches' salves. ${ }^{39}$ They interrogated Stoeckhlin again in November and December, gradually forcing his original narrative to conform to theirs. Stoeckhlin was tortured brutally, and confessed in December to all of the charges in the questionnaire. His ordeal came to an end on 23 January 1587, when he was burned at the stake. He spent over six months in prison, was subjected to tortures which nearly killed him, and was transformed by the official process from a healer and witch-finder into a witch. ${ }^{40}$

There is nothing about Stoeckhlin's case to set him apart from the thousands of other witches who were accused, tried and condemned in early modern Europe. By the time his interrogators were finished, Stoeckhlin had become, from a learned point of view, the most stereotypical witch imaginable. He flew on a goat; he attended the Sabbath, where he and the other witches 'danced, feasted, and copulated'; he had a demon lover; he renounced God and made a pact with the Devil; ${ }^{41}$ he murdered his own children; he practised harmful magic; he had a Devil's mark; and he could transform himself into an animal. ${ }^{42}$ The only thing 'wrong' with the picture is that Stoeckhlin was not an old, poor, marginal woman, but a fairly young man with a family and a decent living.

If we look at Chonrad Stoeckhlin from a perspective coloured by conventional assumptions about male witches, we might be tempted to dismiss him as an aberration who adds nothing to our understanding of witchcraft and gender. A male witch who was accused at the beginning of a witch-hunt, independently of a female relative, ${ }^{43}$ and charged with every diabolic element in the early modern learned concept of witchcraft, looks very strange if one is committed to the idea that 'real' witches are 
necessarily female. This perspective assumes, in effect, that the men who suspected and condemned Chonrad Stoeckhlin made a category error; that they were not conforming to their own intellectual system. This assumption, which appears to be implicit in most work on male witches, is deeply flawed. There is no suggestion, and no reason to believe, that Stoeckhlin'sjudges experienced any sense of cognitive dissonance when confronted by a male witch. On the contrary, they appear to have been committed fully to his 'witchness' from the moment he was first brought to their attention. If those men, supposedly more apt to associate women with witchcraft than we are, could assimilate a male witch within their framework, then we must commit ourselves to doing the same.

Samond and Stoeckhlin were unusual within their specific contexts because they were male witches; but as witches, they were not unusual. Nor were they unique: the same can be said of many other male witches, who also resemble closely the stereotypical (female) witch. For example, witches were feared for their power to cause impotence. In 1658, a man named Besnard appeared before the seigneurial court of Montréal on the charge of having cast a spell on a newly-wed couple that prevented the consummation of their marriage. He was fined and banished. 44

During the famous Salem trials of 1692, six men were hanged as witches. Of these, four were related to female witches, and thus their cases support the generalisation that men were secondary targets of accusations. However, two of the men were not related to accused women.John Willard was a newcomer to Salem Village, and George Burroughs was the former minister of the community. ${ }^{45}$ Burroughs was represented by several witnesses as an extremely powerful wizard, and stands out from the other witches. ${ }^{46}$ Willard, on the other hand, was described as a wholly typical witch who afflicted several individuals, causing illness and death. He even 'suckle[d] the apparition of two black pigs on his breast', just as so many female witches were supposed to have suckled their familiars. ${ }^{47}$

In a more spectacular case, the Jesuit priest Urbain Grandier was executed in 1634 at Loudun, having been found guilty of making a pact 
with the Devil, attending the witches' Sabbath, owning books of magic, and causing the demonic possessions of several Ursuline nuns. Evidence against Grandier included the presence of several Devil's marks on his body. It was very common for witches to be searched for Devil's marks, and for them to be found on or near the sexual organs. These insensitive spots were found in the most secret parts of [Grandier's] body, in the two buttocks close to his anus, and in the two testicles'. ${ }^{48}$ After Grandier's arrest, many of his associates, both male and female, were accused of being witches. ${ }^{49}$

Finally, William Godfrey, a yeoman farmer in New Romney, Kent, was charged with witchcraft in 1617. His neighbours accused him of various maleficia, including laming lambs, killing horses, and killing a child. Godfrey's wife and two children, a son and a daughter, were not accused of witchcraft, and the case against him was thrown out. ${ }^{50}$ That Godfrey's neighbours were serious about their accusations may be inferred from an assault on him. William Clarke attacked Godfrey with a cudgel 'in a vain attempt to extract a confession' after Godfrey joked about bewitching Clarke's mare. ${ }^{51}$

Malcolm Gaskill has pointed out that Godfrey, a middling householder, prosperous farmer and landlord, and active participant in civic life, does not match the stereotype of the 'elderly, marginal widow dependent on charity, or the equally socially-ambivalent younger single woman who fails to meet the conventional expectations of her neighbours, often her female peers'. On the other hand, Gaskill argues, 'Godfrey's story can also be read as a classic tale of fear and maleficium.' The case raises the issue of 'the way historians classify aspects of the past': as Gaskill says, 'we can either explain away the social identity of the accused as an exception to a rule or, more fruitfully, we can redefine the rule to accommodate that identity within a broader interpretative scheme. ${ }^{92}$

Richard Kieckhefer has probed the beginnings on the 'elaborated concept' during the 1430s in the western Swiss canton of Vaud. A slightly later manuscript (Archives Cantonales Vaudoises, Ac 29) shows that of the nineteen people it lists as having been tried for witchcraft 
between 1438 and 1498, twelve were men. In the trials of Pierre Munier (1448) and François Marguet of Dommartin (1498), the men were accused of precisely the same kind of crimes as women were: renouncing God, doing homage to the Devil, attending 'sects' or 'synagogues' of witches, eating the flesh of infants, and misdeeds such as profanation of the Eucharist or killing persons or animals. ${ }^{53}$

Such an interpretative scheme needs to take into account the similarities between male and female witches. As the examples presented in this chapter demonstrate, the social identities of witches were variable, but, once labelled as such, they all fit within the framework of early modern beliefs about witches as Devil-worshippers and practitioners of maleficium. This does not mean that there were no differences between male and female witches. Lyndal Roper has found that in sixteenth-century Augsburg there was 'a gendered specialization in the practice of sorcery itself', which 'emerges most vividly in the different ways male and female sorcerers made use of parts of the body in sorcery.' Men used written spells and 'more exotic bodily relics derived from criminals' (see figure 1), while women used more spoken spells and 'the natural magical properties of the body. ${ }^{54}$ Eva Labouvie and Willem de Blécourt have also found differences in the types of witchcraft attributed to men and women. ${ }^{55}$ These findings are important and certainly worthy of further investigation; however, these fine distinctions should not obscure the fact that conventional modern generalisations about male witches have created a false dichotomy between the men and women accused of witchcraft and have imposed on the past a narrow conception of early modern attitudes toward gender and witchcraft. Gaskill's closing comments about William Godfrey and his accusers are appropriate: 'Godfrey's case may well have been atypical, but to the people of New Romney in 1617 - not least Godfrey himself - it was as valid and real an experience of the European "witch-craze" as any other prosecution in the early modern period. 56

In order to be meaningful, our interpretative frameworks have to be just as capable of accommodating the atypical experiences as they are of 


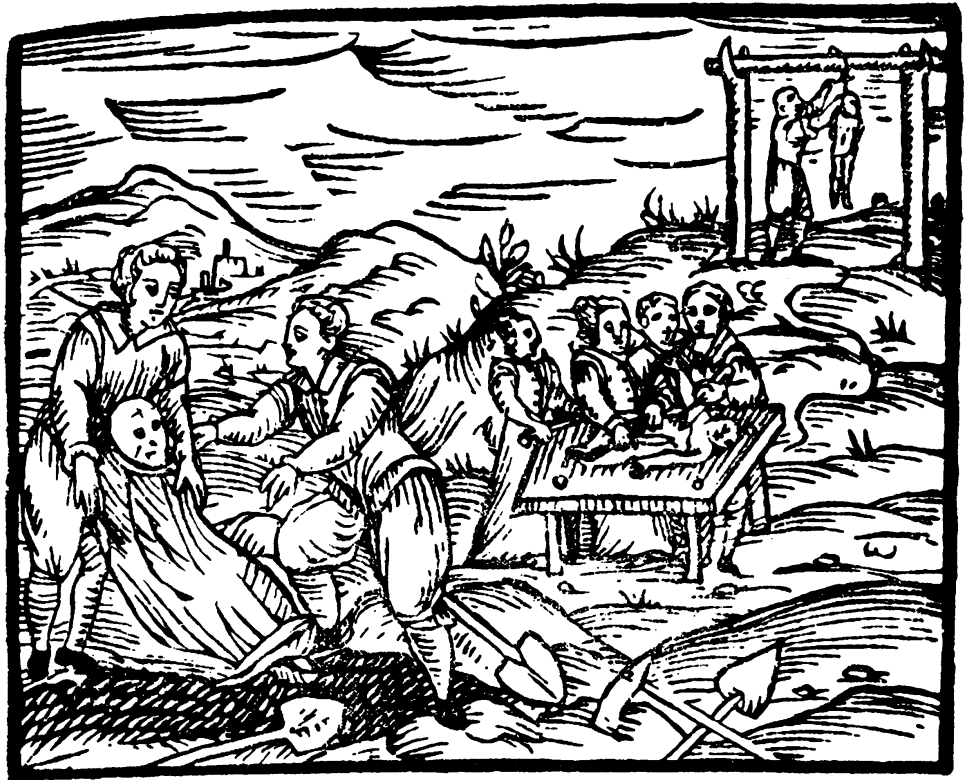

1 Male and female witches exhuming a dead body (foreground), cutting up a dead baby (middle) and cutting down a hanged felon (background), all for the use of body parts and instruments used for executions to make noxious charms, potions and ointments.

accommodating the typical. In the case of early modern ideas about witches, this means adopting a flexible approach to issues of gender that recognises the commonalities between male and female witches and the validity of early modern ideas and experiences.

\section{Notes}

1 Briggs, Witches and Neighbors, 263.

2 Sources for table 1: Monter, Witchcraft in France and Switzerland, 119, table 7; Gabor Klaniczay, 'Hungary: The accusations and the universe of popular magic', Centres and Peripheries, 219-255: 222, table 8.1; Calendar of Assize Records: Essex Indictments: Elizabeth I, ed. J.S. Cockburn (London: HMSO, 1978); Midelfort, Witch Hunting in 
Southwestern Germany, 181, table 14, Karlsen, The Devil in the Shape of a Woman, 48-49, tables 1 and 2; Larner, Enemies of God,91; Hans Eyvind Naess, 'Norway: The criminological context', Centres and Peripheries, 367-382: 371, table 14.1, and 378; Midelfort, Witch Hunting in Southwestern Germany, 181, table 14; Ruth Martin, Witchcraft and the Inquisition in Venice 1550-1650 (Oxford: Basil Blackwell, 1989), 226; Per Sörlin, 'Wicked Arts': Witchcraft and Magic Trials in Southern Sweden, 1635-1754 (Leiden: Brill, 1999), 122, table 5.4; Monter, Witchcraft in France and Switzerland, 119, table 7; Marijke GijswijtHofstra, 'Witchcraft before Zeeland magistrates and church councils, sixteenth to twentieth centuries', Witchcraft in the Netherlands from the Fourteenth to the Twentieth Century, eds. Marijke Gijswijt-Hofstra and Willem Frijhoff, trans. Rachel M.J. van der Wilden-Fall (Rotterdam: Rotterdam University Press, 1991 [1987]), 103-111: 110-111; Monter, Witchcraft in France and Switzerland, 119, table 7; Antero Heikkinen and Timo Kervinen, 'Finland: The male domination', Centres and Peripheries, 319-338: 321; Monter, 'Toads and eucharists', 564 n. 1. Data from the Parlement of Burgundy; Maia Madar, 'Estonia I: Werewolves and poisoners', Centres and Peripheries, 257-272: 267, table 9.2; Monter, 'Toads and eucharists', 584, table 3; Kirsten Hastrup, 'Iceland: Sorcerers and paganism', Centres and Peripheries, 383-401: 386.

3 Joseph Klaits, Servants of Satan: The Age of the Witch Hunts (Bloomington: Indiana University Press, 1985), 51.

4 G.R. Quaife, 'Gender, sex and misogyny: I', Godly Zeal and Furious Rage: The Witch in Early Modern Europe (New York: St Martin's, 1987), 79-96: 81 .

5 Willem de Blécourt has argued that ${ }^{6}[\mathrm{c}]$ ounting women is misleading precisely because they were accused of behaving as non-women, of failing to adhere to the social norm of femininity.' The making of the female witch',293.

6 Macfarlane, Witchcraft in Tudor and Stuart England, 160. Our count of male witches in the Essex records is 24, not 23.

7 Marianne Hester, Lewd Women and Wicked Witches: A Study in the Dynamics of Male Domination (London and New York: Routledge, 1992), 108.

8 Klaits, Servants of Satan, 52.

9 Essex Indictments, record nos. 1084 (Richard and Joan Presmary) and 1010 (Joan Presmary). The indictment for the joint case states that on 10 January 1579 the couple bewitched a bricklayer, Gabriel Smythe, so that he died on 17 July 1579. There is no obvious connection with Joan Presmary's individual case. 
10 Ibid., record no. 620 . The deaths attributed to the Skeltons dated back to 1568.

11 Ibid., record no. 2000. The Dun(n)es were charged with bewitching a gelding and two men. They were found not guilty. The record does not actually state that Agnes was Richard's wife.

12 On the Witchcraft Statute of 1563, see James Sharpe, 'The theological and legal bases for witch-hunting', Instruments of Darkness: Witchcraft in England 1550-1750 (London: Penguin, 1997 [n.p.: Hamish Hamilton, 1996]), 80-102: 90.

13 Essex Indictments, record nos. 95 and 109. In record no. 95, Cockburn gives the dates of death as 29 August for Graunte and 29 May for Pecocke; in record no. 109, the dates are 29 August for Graunte and 28 May for Pecocke. We have accepted the death dates given in C.L'Estrange Ewen, Witch Hunting and Witch Trials: The Indictments for Witchcraft from the Records of 1373 Assizes held for the Home Circuit A.D. 1559-1736 (New York: Dial, 1929),77-78. Transcription and translation of the Chelmsford 1560 indictment, which corresponds to Essex Indictments no 95.

14 Ibid., complete references to John Samond, alias Smythe, Salmon, Smith: record nos. 95, 108-110, 418, 423, 561, 568, 571, 1699-1700, 1704, 1729, 1790, 1792.

15 Ewen, Witch Hunting and Witch Trials, 78. Transcription and translation of the full indictment against Samond, which is listed by Ewen as indictment no. 1.

16 Essex Indictments, record no. 95. Samond was indicted originally in Queen's Bench, but his case was transferred to assizes 30Jan. 1561. He was tried by jury in March 1561 and found not guilty. Record nos. 108-110.

17 Ewen, Witch Hunting and Witch Trials, 77.

18 Ibid., 81. Indictment no. 122 (record no.1063 in Essex Indictments).

19 In Essex Indictments, Cockburn translates 'communis incantator ac fascinator' as 'common wizard'. See our Introduction for comments on the use of 'wizard'.

20 Essex Indictments, record no. 423.

21 Ibid., record nos. 428 (Alice Swallow) and 429 (Alice Bainbricke).

22 Ibid., record no. 571 (Ewen no. 56). Cockburn's version of the indictment is a synthesis of several separate indictments. Ewen's transcription of the charge of harming Edward Robynson is very interesting: the indictment is in Latin, but uses the English words 'witchcraftes inchantementes charmes \& sorceries'. Ewen, Witch Hunting and Witch Trials, 79-80.

23 Essex Indictments, record nos, 580 (Francys) and 582 (Steademan). 
24 Ibid., record nos. 1704 (Samond), 1730 (Joan and Frances Preston), and 1731 (Rose Clarens).

25 Sharpe, Instruments of Darkness, 111.

26 Essex Indictments, record nos. 1792 (Samond), 1795 (Joan Gibson), and 1793 (Alice Bust).

27 Wolfgang Behringer, Shaman of Oberstdorf: Chonrad Stoeckhlin and the Phantoms of the Night, trans. H.C. Erik Midelfort (Charlottesville, VA: Virginia University Press, 1998; orig. Chonrad Stoeckhlin und die Nachtschar: eine Geschichte aus der frühen Neuzeit, Munich, 1994), 116.

28 Ibid., 114. For a summary of the events which places them within a wider German context, see Wolfgang Behringer, Witchcraft Persecutions in Bavaria: Popular Magic, Religious Zealotry and Reason of State in Early Modern Europe, trans. J.C. Grayson and David Lederer (Cambridge: Cambridge University Press, 1997; orig. Hexenverfolgung in Bayern: Volksmagie, Glaubenseifer und Straaträson ïn der Frühen Neuzeit, Munich: 1987), 115-211, esp. 124-5, 177-180.

29 Behringer, Shaman of Oberstdorf, 114.

30 Ibid., 4-6.

31 Ibid., 11-13.

32 Ibid., 17-23. See Behringer for a full discussion of die Nachtschar and parallels with similar folklore, e.g. the benandanti described by Carlo Ginzburg.

33 Ibid., 83.

34 Ibid., 7.

35 Ibid., 84.

36 Ibid., 90-92.

37 Ibid., 92-95.

38 Ibid., 99-100.

39 Ibid., 95.

40 Ibid., 102-105.

41 Ibid., 103-104.

42 Ibid., 100.

43 Behringer places great emphasis on the charge that Stoeckhlin's mother was a witch, stating at one point that 'Stoeckhlin's participation in the society of witches was obviously deduced from the notion that being a witch was inheritable' (ibid., 105). Elsewhere, he suggests that 'being related to a witch was enough to prompt the suspicion that one was a witch'(118). This emphasis seems greatly overstated. According to the chronology of the case, Stoeckhlin was already under suspicion, on totally independent grounds, before anyone mentioned that his mother had been a witch. 
Furthermore, if the inheritability of witchness was so essential, why were Stoeckhlin's wife and children never called for questioning (118)?

44 Jonathan Pearl, 'Witchcraft in New France in the seventeenth century: The social aspect', Historical Reflections/Réflexions Historiques 4, no. 1 (1977): 191-205: 193.

45 Karlsen, The Devil in the Shape of a Woman, 49.

46 'George Burroughs', Salem-Village Witchcraft: A Documentary Record of Local Conflict in Colonial New England, eds. Paul Boyer and Stephen Nissenbaum (Boston: Northeastern University Press, 1993 [1972]), 67-90. Burroughs was said, for instance, to possess extraordinary strength.

47 'Testimony of Susanna Sheldon', Salem-Village Witchcraft, 55-57: 56. Sheldon also testified that Elizabeth Colson 'suckled, as it appeared, a yellow bird'.

48 Robert Rapley, A Case of Witchcraft: The Trial of Urbain Grandier (Montreal and Kingston: McGill-Queen's University Press, 1998), 151. Anne Barstow has emphasised the sexual nature of searching for marks on women's bodies; it can hardly have been less sexual, or less invasive, to search for marks in the private parts of men's bodies.

49 Ibid., 159-162.

50 Gaskill, 'The Devil in the shape of a man', 151-156. Willem de Blécourt has remarked of this case that ' $[\mathrm{t}]$ he accusations of bewitchments against William Godfrey ... can be interpreted within the parameters of Godfrey's reputation as a thief of sheep.' 'The making of the female witch', 308 n. 63.

51 Gaskill, 'The Devil in the shape of a man', 157.

52 Ibid., 158-159.

53 Lecture of 18 March 2002, in the Department of History and Classics, University of Alberta.

54 Roper, 'Exorcism and the theology of the body', Oedipus and the Devil, 171-198: 188-190.

55 de Blécourt, 'The making of the female witch'; Labouvie, 'Männer im Hexenprozess'.

56 Gaskill, 'The Devil in the shape of a man', 170. 